\title{
KUALITAS LIMBAH CAIR EKSTRAKSI SAGU (METROXYLON SP.) MENGGUNAKAN ALAT PENYARING SISTEM BERLAPIS PADA BEBERAPA WAKTU PENYIMPANAN
}

\author{
Sarman Oktovianus Gultom, Paulus Payung, Jefri Yawan \\ Jurusan Teknologi Pertanian, Universitas Papua \\ Jl. Gunung Salju Amban, Manokwari, email : sarmangultom@yahoo.com
}

\begin{abstract}
In order to produce sago starch, sago bar had to be crushed and extracted using water to separate starch from other compounds. In the sago processing, a lot of water was used to extract sago starch and finally was discarded as liquid waste. In this study, the quality of sago liquid waste, before and after applying a layer-based filter containing: coir, charcoal, gravel and sand, was measured. The study was designed with a different time of storage of the Sago liquid waste, namely 0,1,2,3,4, and 5 day of storage. Each day the liquid waste was filterd using layer-based filter, and then the quality of the liquid waste was compared. The parameters measured were total suspended solids, total dissolved solids, final $\mathrm{pH}$, and physical parameters such as smell and color. The results of this study showed that quality decrese of sago liquid waste accurs during 5 days of storage as indicated by increasing the total suspended solids (up to $1400 \mathrm{mg} / \mathrm{L}$ ) and the dissolved solids (up to $2000 \mathrm{mg} / \mathrm{L}$ ), decresing the $\mathrm{pH}$ value (down to 5) and arising unpleasant smells. Furthermore, the use of the layer-based filter was effective enough to restore the quality of the sago liquid water by decreasing the total solids, neutralizing the $\mathrm{pH}$ value and reducing the unpleasant smell.
\end{abstract}

Keyword: Sago, liquid waste, layer-based filter, quality

\section{PENDAHULUAN}

Sagu

(Metroxylon

sp.)

merupakan tanaman asli Asia Tenggara yang penyebarannya meliputi Melanesia Barat sampai India Timur dan dari Mindanao Utara sampai Pulau Jawa dan Nusa Tenggara bagaian selatan. Tanaman sagu tumbuh secara alami terutama di daerah dataran atau rawa dengan sumber air yang melimpah (Limbong, 2007)

Di Papua, sagu dijadikan sebagai salah satu makanan lokal yang banyak dikonsumsi oleh masyarakat karena ketersediaannya yang cukup banyak dan tersebar luas hampir di seluruh wilayah (Haryanto \& Pangloli, 1992). Flach (1997) juga melaporkan bahwa sekitar $45 \%$ dari seluruh areal sagu di dunia terdapat di Papua. Pada umumnya proses pengolahan batang sagu menjadi pati sagu dilakukan dengan cara mengekstraksi pati yang terkandung di dalam empulur sagu dengan bantuan air. Dengan demikian pati sagu dapat dipisahkan dari komponen lainnya (Haryanto \& Siswari, 2004)

Dari keseluruhan tahapan pengolahan sagu, proses ekstraksi menjadi sangat penting karena proses ini akan mempengaruhi rendemen pati sagu yang dihasilkan. Proses ekstraksi biasanya dilakukan di dekat sumber air seperti pinggiran sungai ataupun anak sungai karena membutuhkan air yang banyak hingga mencapai 20.000 liter/ton sagu (Banu et al, 2006). Pada proses ekstraksi, limbah yang dihasilkan dapat berbentuk padat maupun cair Limbah padat pada proses ekstraksi berupa ampas serat sisa perasan, sedangkan limbah cair berupa air yang digunakan pada proses ekstraksi. Menurut Bujang \& Ahmad (2000), untuk menghasilkan $1 \mathrm{Kg}$ tepung sagu akan dihasilkan sekitar 20 Liter air limbah.

Pada umumnya limbah cair yang dihasilkan dari proses ekstraksi tersebut hanya 
dibuang begitu. Limbah cair ekstraksi sagu diduga masih mengandung padatan berupa pati dan ampas serat hasil ekstraksi yang jika dibuang begitu saja secara terus menerus ke sungai atau lahan akan menurunkan kualitas perairan dan memberikan dampak negatif terhadap lingkungan.

Melihat kondisi tersebut, maka perlu untuk dilakukan tindakan awal (pretreatment) terhadap limbah cair ekstraksi sagu sebelum dibuang ke lingkungan. Pengolahan limbah cair hasil ekstraksi sagu juga dapat diduga memiliki potensi untuk dimanfaatkannya kembali (recycle) sebagai air ekstraksi pati sagu. Penerapan alat penyaring sistem berlapis umumnya diaplikasikan untuk penjernihan air bersih dan terbukti efektif dalam mengurangi total padatan yang terkandung di dalamnya. Pada penelitian ini, Kkualitas limbah cair sagu pada beberapa waktu penyimpanan diuji_pada penelitian ini. Selanjutnya, pembuatan dan pengujian alat penyaring sistem berlapis akan dilakukan untuk mengetahui pengaruhnya terhadap kualitas limbah cair yang dihasilkan dari proses ekstraksi sagu.

\section{METODE}

\section{Bahan dan alat}

Bahan utama yang digunakan dalam penelitian ini adalah sagu. Bahan- bahan yang digunakan sebagai media penyaring adalah pasir, kerikil, arang dan serabut kelapa. sedangkan bahan-bahan untuk membuat alat penyaring air sistem berlapis adalah tripleks, kayu lat, kain/kawat has. Peralatan yang digunakan dalam penelitian ini adalah wadah berkapasitas 26 Liter, kran, pompa vakum, kompor listrik, oven, timbangan analitik, $\mathrm{pH}$ meter, autoclave, laminar air flow, inkubator, penghitung sel (cell counter) dan peralatan gelas untuk analisis.

\section{Pelaksanaan Penelitian}

Perancangan dan pembuatan alat penyaring Alat penyaring sistem berlapis ini terdiri dari satu buah wadah plastik berkapasitas 26 Liter yang bagian dalamnya tersusun atas beberpa lapisan. Adapun susunan lapisan pada alat penyaring ini (dari lapisan teratas hingga lapisan terbawah) adalah sebagai berikut: serabut kelapa $(5 \mathrm{~cm})$, arang tempurung kelapa $(5 \mathrm{~cm})$, kerikil (5 $\mathrm{cm})$, pasir $(10 \mathrm{~cm})$, dan serabut kelapa $(5 \mathrm{~cm})$. Desain alat penyaring sistem berlapis yang digunakan pada penelitian ini dapat dilihat pada Gambar 1.
Comment [P1]: Adakah riset sebelumnya dari peneliti lain yang menangani limbah sagu? Kelebihan penelitian ini bedanya dan keunggulannya apa? Sehingga memperkuat tulisan

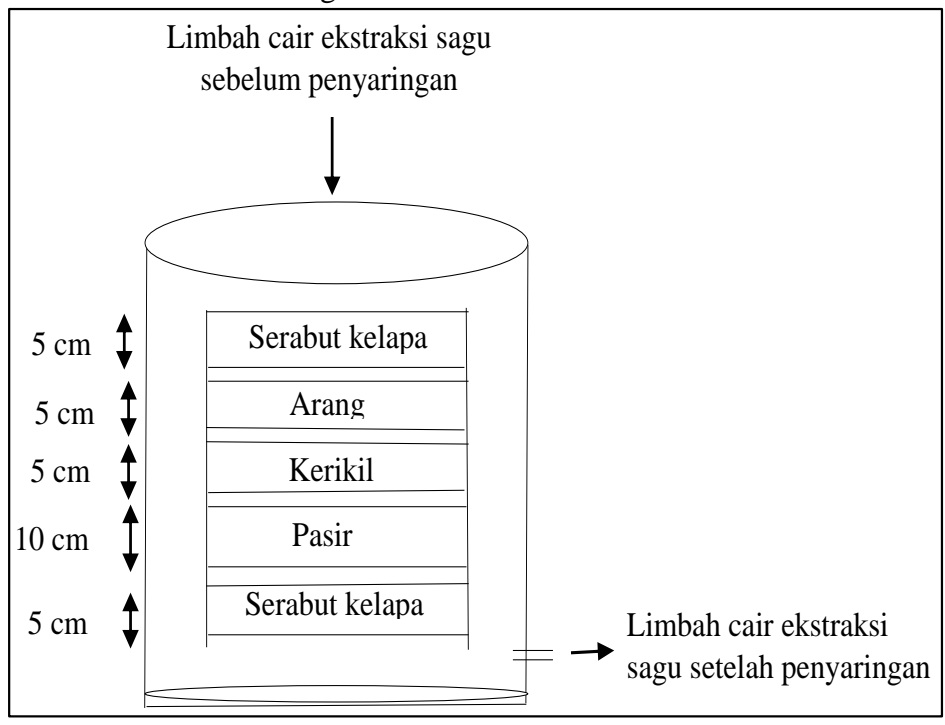

Gambar 1. Desain Alat Penyaring Air Sistem Berlapis 


\section{Pengujian kualitas limbah cair ekstraksi sagu sebelum disaring}

Pengujian kualitas limbah cair dilakukan setelah proses ekstraksi sebelum dilakukan penyaringan. Limbah cair hasil proses ekstraksi ditampung pada sebuah wadah lalu disimpan pada suhu ruang dengan waktu penyimpanan $0,1,2,3,4$ dan 5 hari. Pengujian kualitas limbah dilakukan setiap harinya.

\section{Pengujian kualitas limbah cair ekstraksi sagu setelah disaring}

Limbah cair ekstraksi sagu dilewatkan pada alat penyaring sistem berlapis yang telah dibuat. Lama waktu penyaringan berkisar 15-20 menit hingga seluruh limbah cair tersebut melewati lapisan yang tersusun pada alat penyaring. Limbah cair yang telah melewati alat penyaring tersebut kemudian dianalisis. Pengujian alat dilakukan terhadap limbah cair ekstraksi sagu yang dibiarkan pada suhu ruang dengan waktu penyimpanan $0,1,2,3,4$ dan 5 hari.

\section{Parameter yang diamati}

Parameter yang digunakan adalah parameter fisik dan kimia yaitu padatan tersuspensi, padatan terlarut, suhu, warna, bau dan $\mathrm{pH}$ dari limbah cair ekstraksi sagu sebelum dan sesudah disaring selama 5 hari penyimpanan.

\section{Prosedur Analisis}

\section{Analisis Padatan Tersuspensi}

Analisis padatan tersuspensi dilakukan dengan mengacu pada SNI 066989.3-2004. Sampel limbah cair ekstraksi sagu dikocok hingga homogen dan dipipet sebanyak $50 \mathrm{~mL}$ dan dilakukan penyaringan menggunakan corong gelas dan kertas saring yang telah diketahui beratnnya. Kemudian kertas saring diambil dengan hati-hati dan diletakkan di atas cawan untuk dipanaskan didalam oven dengan suhu $105^{\circ} \mathrm{C}$ selama 1 jam. Selanjutnya didinginkan dalam desikator dan timbang segera dengan neraca analitik hingga diperoleh berat konstan. Padatan tersuspensi dihitung dengan persamaan berikut :

$$
\begin{aligned}
& \text { Padatan Tersuspensi } \\
& =\frac{(A-B) \times 1.000 .000}{a}(\mathrm{mg}
\end{aligned}
$$

$$
\text { /L) } \ldots \ldots \ldots \ldots(1)
$$

Keterangan :

$\mathrm{A}=$ Berat tetap kertas saring + residu $(\mathrm{g})$

$\mathrm{B}=$ Berat kertas saring kosong $(\mathrm{g})$

$\mathrm{a}=$ Volume sampel $(\mathrm{ml})$

\section{Analisis Padatan Terlarut}

Analisis padatan terlarut dilakukan dengan menggunakan acuan SNI 06-6989.272005. Sampel limbah ekstraksi sagu dikocok hingga homogen dan dipipet sebanyak $50 \mathrm{~mL}$ dan dilakukan penyaringan menggunakan corong gelas dan kertas saring. Sampel yang lolos dari kertas saring dituang ke dalam cawan allumunium. Selanjutnya, cawan yang berisi sampel tersebut diuapkan dan dikeringkan dalam oven pada suhu $105^{\circ} \mathrm{C}$ sampai semua air menguap. Setelah itu cawan dikeluarkan dari oven menggunakan penjepit cawan untuk didinginkan dalam desikator dan ditimbang segera dengan neraca analitik hingga diperoleh berat konstan. Padatan terlarut dihitung dengan persamaan berikut :

\section{Padatan Terlarut}

$$
=\frac{(C-D) \times 1.000 .000}{a}(\mathrm{mg}
$$$$
\text { /L) } \ldots \ldots \ldots \ldots
$$

Keterangan :

$\mathrm{C}=$ Berat tetap cawan + Residu $(\mathrm{g})$

$\mathrm{D}=$ Berat cawan kosong $(\mathrm{g})$

$\mathrm{a}=$ Volume sampel $(\mathrm{ml})$

\section{Pengukuran Suhu}

Pengukuran Suhu dilakukan dengan menggunakan acuan SNI 06-6989.23-2005. Sampel limbah ekstraksi sagu dimasukan dalam gelas erlenmeyer, masukkan termometer yang bersih dan kering kedalam gelas erlenmeyer yang berisi contoh sampel, biarkan selama 5 menit, baca dan catat suhu yang tertera pada termometer.

\section{Pengujian Warna dan Bau}

Pengujian warna dan bau dilakukan dengan menggunakan acuan SNI 06-6989.252005. Pengujian warna dan bau limbah cair ekstraksi sagu dilakukan berdasarkan
Comment [P2]: Berapa lama wakt penyaringannya? 
pengindraan manusia (organoleptik). Sampel limbah cair sebelum dan sesudah penyaringan dimasukan ke dalam erlenmeyer dan diamati perbandingan warnanya secara visual. Pengujian bau limbah cair ekstraksi sagu dilakukan dengan cara sampel dimasukan ke dalam sebuah botol tertutup ( $1 / 2$ hingga $3 / 4$ ), botol berisi sampel kemudian dikocok dengan kuat kemudian tutup botol dibuka dan bau dari sampel dibaui melalui mulut botol.

\section{Pengukuran pH}

Pengukuran $\mathrm{pH}$ dilakukan dengan menggunakan acuan SNI 06-6989.11-2004. Sampel limbah cair ekstraksi sagu dimasukkan pada gelas kimia, kalibrasi alat pH meter, bilas elektroda dengan aquadest, keringkan dengan tissue, masukkan elektroda ke gelas kimia yang berisi sampel limbah cair ekstrasi sagu dan baca skala yang ditunjukkan pH meter jika angkanya sudah konstan.

\section{HASIL DAN PEMBAHASAN}

\section{Padatan Terlarut}

Hasil pengamatan padatan tersuspensi sebelum dan sesudah penyaringan selama 5 hari penyimpanan dapat dilihat pada Gambar 2. Hasil pengamatan menunjukkan bahwa semakin lama limbah cair ekstraksi sagu disimpan, maka konsentrasi padatan yang tersuspensi pada limbah cair tersebut juga semakin tinggi. Hal ini diduga disebabkan karena adanya peningkatan jumlah jasad renik dalam limbah cair selama penyimpanan di ruang terbuka. Setelah dilakukan penyaringan dengan menggunakan alat penyaring sistem berlapis, terlihat bahwa konsentrasi padatan tersuspensi mengalami penurunan. Rata-rata efektifitas penurunan konsentrasi padatan tersuspensi yaitu sebesar $60 \%$. Meskipun telah dilakukan penyaringan, data pada hari ke-4 menunjukkan bahwa konsentrasi padatan tersuspensi pada limbah cair ekstraksi sagu telah mencapai $457 \mathrm{mg} / \mathrm{L}$. Konsentrasi tersebut telah melampaui strandar baku mutu limbah cair yang telah ditentukan, yaitu sebesar $400 \mathrm{mg} / \mathrm{L}$ (keputusan Menteri Negara Lingkungan Hidup no: kep51/menlh/10/1995). Hasil tersebut mengindikasikan bahwa penyaringan limbah cair ekstraksi sagu hanya efektif dilakukan pada limbah cair yang telah tersimpan hingga 3 hari.

Penurunan konsentrasi padatan tersuspensi terjadi karena media penyaring (arang, pasir dan kerikil) bekerja dengan baik sesuai fungsinya masing-masing. Arang tempurung kelapa mengandung karbon dan bersifat lunak apabila kontak dengan air yang akan disaring sehingga permukaan arang lebih mudah mengadsorpsi zat-zat yang akan dihilangkan termasuk padatan tersuspensi. Adsorpsi yang terjadi diduga diakibatkan karena adanya medan gaya pada permukaan adsorben (karbon) yang menarik molekulmolekul adsorban (limbah cair). Pada proses ini, partikel atau molekul bahan pencemar dalam limbah cair akan menempel pada permukaan karbon yang disebabkan adanya perbedaan muatan yang lemah (gaya Van der Waals) diantara keduanya sehingga membentuk suatu lapisan tipis partikelpartikel halus pada permukaan karbon.

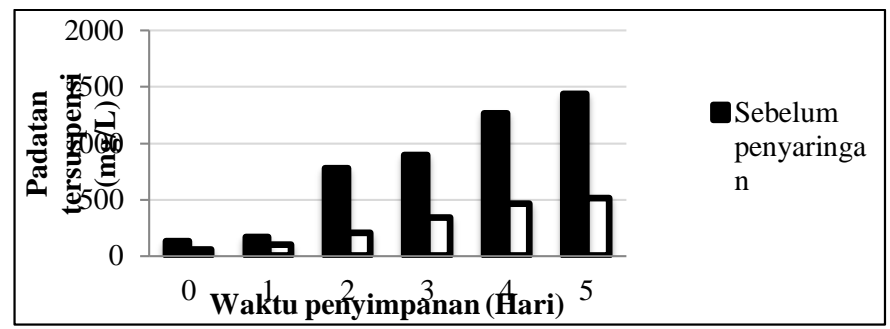

Gambar 2. Padatan Tersuspensi Limbah Cair Ekstraksi Sagu Sebelum dan Sesudah Penyaringan Selama 5 Hari Penyimpanan. 


\section{Padatan Terlarut}

Hasil pengamatan padatan terlarut sebelum dan sesudah penyaringan pada 5 hari penyimpanan dapat dilihat pada Gambar 3. Limbah cair ekstraksi sagu sebelum penyaringan mengandung padatan terlarut yang tinggi, namun setelah dilakukan penyaringan dengan menggunakan alat penyaring air sistem berlapis mengalami penurunan. Rata-rata efektifitas penurunan konsentrasi padatan terlarut yaitu sebesar $82 \%$. Limbah cair ekstraksi sagu setelah penyaringan menunjukkan bahwa konsentrasi padatan terlarut pada hari ke-3 telah mencapai $4620 \mathrm{mg} / \mathrm{L}$. Konsentrasi tersebut telah melampaui strandar baku mutu limbah cair yang telah ditentukan, yaitu sebesar 4000 mg/L (keputusan Menteri Negara Lingkungan
Hidup no: kep-51/menlh/10/1995). Hasil tersebut mengindikasikan bahwa penyaringan limbah cair ekstraksi sagu hanya efektif dilakukan pada limbah cair yang telah tersimpan hingga 2 hari.

Seperti halnya pada padatan tersuspensi, penurunan nilai padatan terlarut terjadi karena media penyaring (arang, pasir dan kerikil) bekerja dengan baik sesuai fungsinya masing-masing. Arang tempurung kelapa diduga dapat mengadsorpsi komponenkomponen yang larut dalam air karena adanya perbedaan muatan antara permukaan karbon dan bahan yang diserap. Hal ini didukung oleh Wijaya (2008) yang melaporkan bahwa karbon aktif dapat mengadsorpsi molekul bahan pencemar hingga tercapai kondisi setimbang.

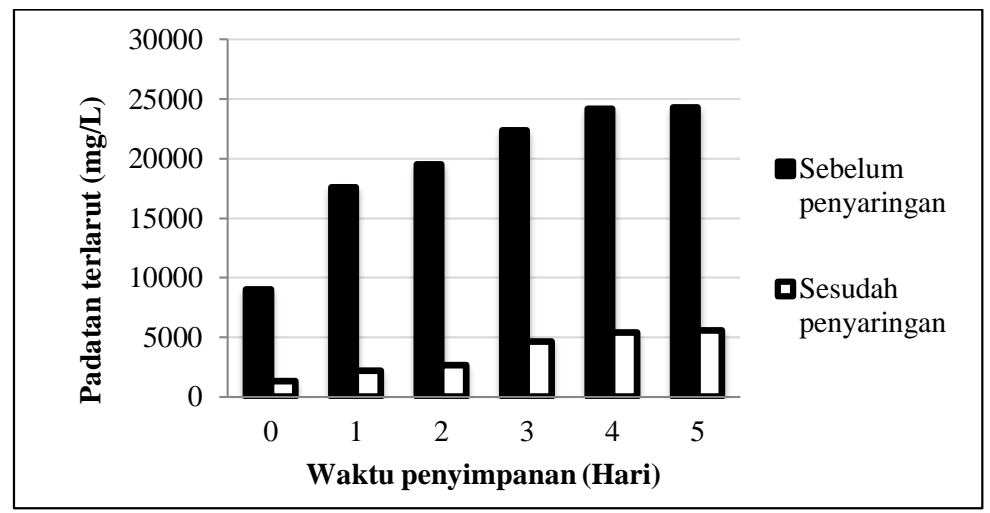

Gambar 3. Padatan Terlarut Limbah Cair Ekstraksi Sagu Sebelum dan Sesudah Penyaringan Selama 5 Hari Penyimpanan.

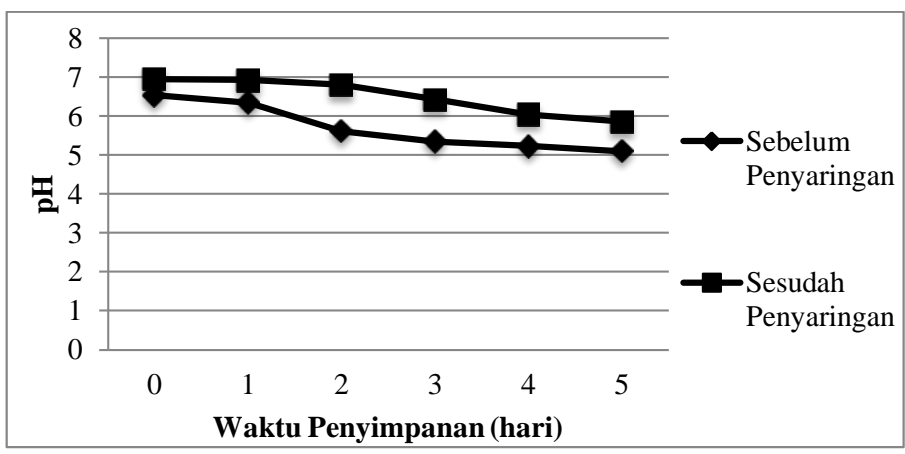

Gambar 4. Nilai pH Limbah Cair Ekstraksi Sagu Sebelum dan Sesudah Penyaringan Selama 5 Hari Penyimpanan. 
pH

$\begin{array}{rrl} & \mathrm{pH} & \text { adalah istilah yang } \\ \text { digunakan untuk } & \text { menyataan intensitas }\end{array}$ keadaan asam atau basa sesuatu larutan. Dalam penyediaan air, $\mathrm{pH}$ merupakan satu faktor yang harus dipertimbangkan mengingat bahwa derajat keasaman dari air akan sangat mempengaruhi aktivitas pengolahan yang akan dilakukan, misalnya dalam melakukan koagulasi kimiawi, desinfeksi, pelunakan air dan dalam pencegahan korosi (Suhartana, 2006). Hasil pengamatan $\mathrm{pH}$ sebelum dan sesudah penyaringan pada 5 hari penyimpanan dapat dilihat pada Gambar 4.

Hasil pengukuran nilai $\mathrm{pH}$ limbah cair sagu sebelum dilakukan penyaringan menunjukkan bahwa selama 5 hari penyimpanan limbah cair sagu mengalami penurunan $\mathrm{pH}$ singga mencapai 5,0 pada hari ke-5. Penurunan $\mathrm{pH}$ terjadi karena pada awal perombakan, sejumlah mikroorganisme tertentu akan mengubah sampah organik menjadi asam organik (Khori, 2010). Namun $\underline{S}$ setelah dilakukan penyaringan__-peningkatan $\mathrm{pH}$ limbah cair sagu terjadi. Peningkatan $\mathrm{pH}$ sesudah penyaringan diduga karena pengaruh penggunaan arang yang kaya akan ion $\mathrm{C}$ mampu mengikat ion $\mathrm{H}$ yang terkandung pada limbah cair sehingga $\mathrm{pH}$ kembali stabil.
Bau

Bau merupakan petunjuk adanya pembusukan air limbah. Penyebab adanya bau pada air limbah karena adanya bahan volatil, gas terlarut dan hasil samping dari pembusukan bahan organik. Bau yang dihasilkan oleh air limbah pada umumnya berupa gas yang dihasilkan dari peruraian zat organik yang terkandung dalam air limbah, seperti hidrogen sulfida $\left(\mathrm{H}_{2} \mathrm{~S}\right)$ (Sihaloho, 2008). Pengujian bau pada limbah cair ekstraksi sagu dilakukan secara organoleptik seperti yang tersaji pada Tabel 1.

Limbah cair ekstraksi sagu mulai berbau pada penyimpanan hari ke-1. Menurut Suhenry (1993), adanya perubahan bau pada limbah cair dapat disebabkan karena adanya bahan-bahan kimia yang terlarut atau tersuspensi serta terdapatnya ganggang, plankton, ataupun hewan air yang sudah mati atau membusuk. Pada penyimpanan hari ke-2 hingga hari ke-5, pengujian bau limbah cair sebelum disaring menunjukkan adanya perubahan bau menjadi bau asam kuat dan sedikit bau busuk. Hal ini terjadi karena adanya proses penguraian senyawa organik oleh mikroorganisme pada limbah cair tersebut. Nammn, $\$ \underline{S}$ etelah dilakukan penyaringan, bau asam tersebut telah berkurang dan baunya kembali menjadi normal khas sagu.
Comment [P4]: Kata sambung bolehkah di awal kalimat

Comment [P5]: Mohon dikonfirmasi pada redaksi bolehkah kata sambung di awal kalimat

Tabel 1. Bau Limbah Cair Ekstraksi Sagu Sebelum dan Sesudah Penyaringan

\begin{tabular}{clc}
\hline Waktu penyimpanan (Hari) & Sebelum Penyaringan & Sesudah Penyaringan \\
\hline 0 & Tidak bau & Tidak bau \\
1 & Bau & Tidak bau \\
2 & Sangat bau & Agak bau \\
3 & Sangat bau & Agak bau \\
4 & Sangat bau & Agak bau \\
5 & Sangat bau & Agak bau \\
\hline
\end{tabular}

Tabel 2. Warna Limbah Cair Ekstraksi Sagu Sebelum dan Sesudah Penyaringan

\begin{tabular}{ccc}
\hline Waktu penyimpanan (Hari) & Warna Sebelum Penyaringan & Warna Sesudah Penyaringan \\
\hline 0 & Coklat kemerahan & Kuning bening \\
1 & Coklat kemerahan & Kuning bening \\
2 & Coklat kemerahan & Kuning bening \\
3 & Coklat kemerahan & Kuning bening \\
4 & Coklat kemerahan & Kuning bening \\
5 & Coklat kemerahan & Kuning bening \\
\hline
\end{tabular}




\section{Warna}

Hasil pengamatan warna pada limbah cair ekstraksi sagu dilakukan secara secara visual seperti yang tersaji pada Tabel 2 . Limbah cair ekstraksi sagu setelah proses ekstraksi berwarna coklat kemerahan, bahkan hingga hari ke-5 penyimpanan. Namun, setelah dilakukan penyaringan, warna limbah cair tersebut terlihat lebih bening kekuningan. Warna coklat kemerahan pada limbah cair ekstraksi sagu sebelum penyaringan diduga disebabkan karena terjadi reaksi browning pada komponen-komponen organik dalam limbah cair sagu. Limbah cair tersebut diduga masih mengandung subtrat senyawa fenolik yang teroksidasi oleh enzim fenol oksidase (Winarno, 1997).

$$
\text { Perubahan warna pada air }
$$
disebabkan adanya zat padat terlarut atau zat padat tersuspensi. Jenie \& Rahayu (1993) menyatakan bahwa padatan tersuspensi mempengaruhi kekeruhan dan warna air. Perubahan warna sesudah penyaringan disebabkan karena menurunnya nilai zat padat terlarut dan zat padat tersuspensi yang menyebabkan limbah ekstraksi sagu menjadi lebih jernih.

\section{KESIMPULAN}

Penurunan kualitas limbah cair ekstraksi sagu terjadi selama 5 hari penyimpanan yang ditunjukkan dengan meningkatnya total padatan tersuspensi dan padatan terlarut, penurunan nilai $\mathrm{pH}$ serta timbulnya bau kurang sedap yang mengindikasikan terjadinya penguraian bahan organik oleh mikroorganisme. Dari hasil penelitian ini juga dapat disimpulkan bahwa pPenggunaan alat penyaring sistem berlapis cukup efektif mengembalikan kualitas limbah cair dengan menurunkan total padatan, Menetralkan -menetralkan nilai $\mathrm{pH}$ serta mengurangi warna keruh pada limbah cair.

\section{DAFTAR PUSTAKA}

Banu J RSK and DB. 2006. Treatment of Sagu Wastewater Using Hybrid Anaerobic Reactor. Water Qual, Res. J, 1(41): 56-62.

Bujang K and Ahmad FB. 2000. Country Report of Malaysia; Production and Utilization of Sago Starch in Malaysia.
Prosiding Internasional Sago Seminar: 1-8.

Flach M. 1997. Sago palm: Metroxylon sagu Rottb. Sago palm: Metroxylon sagu Rottb.

Haryanto B dan Siswari E. 2004. Pengaruh Usaha Pengolahan Skala Kecil Terhadap Baku Anak Air Sungai. Studi Kasus Industri Pengolahan Sagu di Kelurahan Cibuluh, Kota Bogor. $J$. Tek.Ling.P3TL-BPPT.5. (3): 221-226

Haryanto B dan Pangloli P. 1992. Potensi dan Pemanfaatan Sagu. Kanisius. Yogyakarta.

Limbongan 2007. Morfologi Beberapa Jenis Sagu Potensial di Papua. Jurnal Litbang Pertanian, Vol. 36: 16-19.

Menteri Negara Lingkungan Hidup. 1995. Baku Mutu Limbah Cair Bagi Kegiatan Industri.

Silvana S. 2009. Perencanaan Sistem Pengolahan Limbah Cair Tahu PT. AS Tanah Baru Depok. FKMI, UI.

Standar Nasional Indonesia. 2004. Air dan Air Limbah-Bagian 11: Cara Uji Derajat Keasaman $(p H)$ dengan Menggunakan Alat pH Meter. 06-6989.11-2004.

Standar Nasional Indonesia. 2004. Air dan Air Limbah-Bagian 3 : Cara Uji Padatan Tersuspensi Total (Total Suspended Solid, TSS) Secara Grafimetri. 066989.3-2004.

Standar Nasional Indonesia. 2005. Air dan Air Limbah-Bagian 24: Cara Uji Suhu dengan Termometer. 06-6989.23-2005.

Standar Nasional Indonesia. 2005. Air dan Air Limbah-Bagian 24: Cara Uji Warna Secara Perbandingan Visual. 066989.24-2005.

Standar Nasional Indonesia. 2005. Air dan Air Limbah-Bagian 27: Cara Uji Kadar Padatan Terlarut Total Secara Gravimetri. 06-6989.27-2005.

Suhartana. 2006. Pemanfaatan Tempurung Kelapa Sebagai Bahan Baku Arang Aktif dan Aplikasinya untuk Penjernihan Air Sumur di Desa Belor Kecamatan Ngaringan Kabupaten Grobongan. Jurnal Fisika. Vol. 9, No. 3. 2006 : 151-156.

Winarno FG. 1997. Kimia Pangan dan Gizi. Penerbit PT. Gramedia pustaka Utama, Jakarta 1997.
Comment [P6]: Salah ejaan

Comment [P9]: Ejaan salah

Comment [P7]: Kalimat yang diblok tidak diperlukan

Comment [P8]: Tulisan huruf keci 